\title{
Effect of the nature and amount of dietary energy on lipid composition of rat gingival tissue
}

\author{
By SALIL K. DAS, MUNALULA L. ELLIOTT and HALIFAX C. KING \\ Department of Biochemistry and Nutrition, Meharry Medical College, Nashville, \\ Tennessee 37208, USA
}

(Received 24 January 1982 - Accepted 21 October 1982)

1. The effect of the nature and amount of dietary energy on the lipid composition of rat gingival tissue was studied. Male weanling rats were given one of three iso-energetic diets: high-carbohydrate, high-protein and extremely high-protein, or a fourth high-fat diet, for $49 \mathrm{~d}$.

2. The high-carbohydrate, extremely high-protein and high-fat diets caused significant increases in the gingival levels of total lipids compared with the normal-protein diet. These increases in total lipids were due primarily to increases in the levels of triglycerides and cholesterol esters. There were no significant differences in the fatty acid compositions of either non-polar or polar lipids among rats given the high-carbohydrate diet and those given the high-protein diet.

3. A comparison of the fatty acid composition of lipids of rats given the extremely high-protein diet and the other two iso-energetic diets revealed that the proportion of palmitic acid was higher and the proportion of oleic acid was lower in animals given the extremely high-protein diet than in animals given the other two diets. Compared with the three iso-energetic low-fat diets, the high-fat diet caused decreases in the proportion of palmitic and palmitoleic acids and increases in the proportion of linoleic, arachidonic and docosapentaenoic acids in total fatty acids of both non-polar and polar lipids. It should be noted that the high-fat diet contained a high proportion of linoleic acid and it is expected that this diet would raise the 18:2 fatty acid content of the lipids and aiso would raise the 20:4 and 22:5 levels as 18:2 is an essential fatty acid and will, with its metabolites, be directly incorporated into tissue lipids.

Considerable information is available in the literature regarding the relationship of diet with health conditions of gingival tissue. Wysocki \& Ziombski (1963) reported that feeding high-sugar diets containing animal fats produced periodontal changes in the rat. But when the high-sugar diet contained soya-bean oil instead of animal fat there were no periodontal changes. They concluded that the type of dietary fat was important in the production of these changes. Stahl (1963) reported that gingival wounds in animals given a protein-free diet showed a delay in connective tissue repair. Prout \& Tring $(1971 a, b)$ showed that feeding an essential-fatty-acid-deficient diet produced histological changes in oral tissues of rats. For example, the animals on the fat-free diet lost the normal colour of the gingival tissue and there was a space of varying width and depth between the gingiva and the teeth. However, it is not known whether the periodontal changes associated with diet were related to biochemical compositional changes in gingival tissue. Several studies on the lipid composition of gingival tissue have been reported (Rabinowitz et al. 1971; Das et al. 1976 a, $b, c)$. Most of the lipids are contained in the lamina propria; the most predominant surface lipids are cholesterol, cholesterol esters and phospholipids as compared with the typical stored triglycerides of the deeper layers (Das et al. 1976a). It is known (Abdel-Hay et al. 1968) that dietary lipids markedly influence the lipid composition of various soft tissues of animals. However, the influence of dietary lipids on the composition of gingival tissue lipids has not been investigated. Also, it is not known whether the nature and amount of dietary energy can influence the lipid composition of gingival tissue. The purpose of the present study was to determine the effect of the amount and the nature of dietary energy as fat, carbohydrate and protein on the lipid composition of the gingival tissue of rats. It must be noted that the effect of the different diets on the lipid composition of the tissues 
Table 1. Composition of experimental diets $(\mathrm{g} / \mathrm{kg})$

\begin{tabular}{|c|c|c|c|c|}
\hline \multirow[b]{2}{*}{ Ingredients* } & \multicolumn{4}{|c|}{ Diets } \\
\hline & 1 & 2 & 3 & 4 \\
\hline Casein (vitamin-free) & 180 & 290 & 590 & 290 \\
\hline Sucrose & 200 & 200 & 200 & 200 \\
\hline Maize starch & 480 & 370 & 70 & 100 \\
\hline Brewers' yeast & 20 & 20 & 20 & 20 \\
\hline Cottonseed oil $\dagger$ & 80 & 80 & 80 & 350 \\
\hline Salt mixture $\ddagger$ & 40 & 40 & 40 & 40 \\
\hline Vitamin mixture $(\mathrm{mg} / \mathrm{kg}) \|$ & $3 \cdot 36$ & $3 \cdot 36$ & $3 \cdot 36$ & $3 \cdot 36$ \\
\hline \multicolumn{5}{|l|}{ Percentage energy as: } \\
\hline Protein & $17 \cdot 0$ & $28 \cdot 0$ & $57 \cdot 0$ & $21 \cdot 0$ \\
\hline Carbohydrate & $19 \cdot 0$ & $19 \cdot 0$ & $19 \cdot 0$ & $15 \cdot 0$ \\
\hline Maize & 47.0 & $36 \cdot 0$ & $7 \cdot 0$ & $7 \cdot 0$ \\
\hline Fat & 17.0 & 17.0 & $17 \cdot 0$ & $57 \cdot 0$ \\
\hline Energy value (MJ/kg) & $17 \cdot 4$ & 17.4 & $17 \cdot 4$ & $23 \cdot 1$ \\
\hline Energy as fat & \multirow[t]{2}{*}{0.26} & \multirow[t]{2}{*}{$0 \cdot 31$} & \multirow[t]{2}{*}{0.65} & \multirow[t]{2}{*}{$2 \cdot 6$} \\
\hline$\overline{\text { Energy as carbohydrate }}$ & & & & \\
\hline
\end{tabular}

* Nutritional Biochemical Corp., Cleveland, Ohio.

$\dagger$ Fatty acid composition $(\mathrm{g} / \mathrm{kg})$ : myristic 25 , palmitic 256 , stearic 51 , oleic 252 , linoleic 412 , linolenic 4 .

$\ddagger$ US Pharmacopoea (1945).

I| Vitamin fortification mix containing $(\mathrm{mg} / \mathrm{g}$ mixture): cholecalciferol $0 \cdot 25, \alpha$-tocopherol $5 \cdot 0$, ascorbic acid 45.0, myoinositol $5 \cdot 0$, choline chloride $75 \cdot 0$, menadione $2 \cdot 25, p$-aminobenzoic acid $5 \cdot 0$, niacin $4 \cdot 5$, riboflavin $1 \cdot 0$, pyridoxine hydrochloride 1.0 , thiamin hydrochloride 1.0 , calcium pantothenate 3.0 and $(\mu \mathrm{g} / \mathrm{g}$ mixture): biotin $20 \cdot 0$, folic acid $90 \cdot 0$ and cyanocobalamin $1 \cdot 35$.

will be quite different from the effect on the fatty acid composition of the lipids. A high-carbohydrate diet or high-fat diet from which non-essential fatty acids will be synthesized, will alter the proportions of fatty acids incorporated into lipids.

\section{MATERIALS AND METHODS}

\section{Animals and diets}

Male, 21-d-old weanling rats of the Sprague-Dawley strain were assigned to four dietary treatments of thirty rats each on the basis of body-weight and litter mates. All animals, housed singly and randomly in raised-screen wire cages in air-conditioned animal quarters, had free access to water and were given ad lib. the appropriate diets (Table 1) for a total of $49 \mathrm{~d}$. Diets 1, 2 and 3 were iso-energetic, identical in the level and source of fat but different in protein energy: carbohydrate energy value. Diet 4 contained the same amount of protein as diet 2 on a weight basis, but the fat content had been increased from 80 to $350 \mathrm{~g} / \mathrm{kg}$ to increase the energy value from 17.4 to $23 \cdot 1 \mathrm{MJ} / \mathrm{kg}$. All diets contained the same amount of brewer's yeast, vitamins, and minerals on a weight basis, but the ratios of these components to energy value were appreciably less in diet 4 than in diets $1-3$. A record was kept of food consumption and body-weight gain of each animal during the experimental period.

\section{Tissue samples}

At the end of the experiment, animals were killed by decapitation. Gingival specimens were obtained from the buccal and lingual areas of the oral cavity, and processed in a manner similar to that used by Das et al. $(1976 a)$. 


\section{Chemical assays}

Lipids were extracted and purified from gingival tissues according to the procedure described in an earlier report (Das et al. 1976a). Lipids were separated into two major fractions on a silicic acid column by the successive use of chloroform and methanol solutions. Evaporation was done in vacuum by means of a rotary evaporator at $40-50^{\circ}$, and the residue was dried over phosphoric anhydride in a vacuum desiccator. A preparative silica gel thin-layer chromatograph (TLC) was done with the chloroform and methanol fractions in order to isolate individual non-polar and phospholipid classes respectively (Mangold \& Malins, 1960; Parker \& Peterson, 1965). The quantities of free cholesterol and total cholesterol were determined in the total chloroform eluate by adapting the procedure of Courchaine et al. (1959). Triglycerides and free fatty acids isolated from TLC plates were assayed by the methods of Van Handel \& Zilversmit (1957) and Novak (1965) respectively. The amounts of mono- and diglycerides were obtained by substracting the combined amounts of cholesterol esters, triglycerides, free fatty acids and free cholesterol from the amounts of total non-polar lipids. The quantities of total phospholipids and phosphatidyl choline isolated from the TLC plates were determined by measuring the amount of phosphorus according to the procedure of Bartlett (1958). The fatty acid composition of total non-polar and total polar lipids was determined by gas-lipid chromatography (GLC) of their fatty acid esters (Metcalf \& Schmitz, 1961) according to the conditions described earlier (Das et al. 1975). When necessary, fractions isolated by GLC were identified after hydrogenation and rechromatography of the saturated derivatives.

\section{Statistical analysis}

Results were treated statistically using the Student's $t$ test (Steel \& Torrey, 1960). The variability of the results is presented as values with their standard errors. Differences at $P<0.05$ were considered significant.

\section{RESULTS}

Results relating to the effect of diet on growth, mortality rate and feed efficiency of rats are shown in Table 2. When the three iso-energetic diets (diets 1,2 and 3) were fed, the average body-weight gain for diet 1 was less than that for diet 2 , but almost equal to that for diet 3 . The average body-weight gain of animals on the high-fat diet (diet 4) was greater than that of the animals on diets 1 and 3 , but less than that of animals on diet 2. No significant difference in feed efficiency occurred between the four groups of animals; however the energetic efficiency of diet $\mathbf{4}$ was greater than that of the other three diets, those three diets having approximately the same energetic efficiency. A high mortality rate was observed only among rats given the extremely high-protein diet (diet 3). A sampling of blood chemistries of this group showed a high blood urea value, e.g. blood urea-nitrogen of $400-500 \mathrm{mg} / \mathrm{l}$. All deaths in this group occurred within 2 weeks of the start of the experiment and it was not known whether the deaths were related to diet.

Results relating to the effect of diet on the nature and amount of lipids in gingiva are shown in Table 3. Compared with the high-protein diet, the high-carbohydrate, extremely high-protein and high-fat diets caused significant increases in the levels of total lipids in gingival tissue. The levels of total polar lipids were almost similar in rats of all groups. Phosphatidyl choline, phosphatidyl ethanolamine and sphingomyelin were the major phospholipid spots on TLC plates in each group. In addition, phosphatidic acid, phosphatidyl serine and phosphatidyl inositol were detected as minor components in each group. The average increases in total lipids were due to increases in the levels of glycerides and cholesterol esters. Results relating to the effect of diet on the acyl group composition of 
Table 2. Effect of diet on mortality rate, growth, feed efficiency and energetic efficiency of rats

(Mean values with their standard errors, no. of animals given in parentheses (no. at start and end of experiment respectively))

\begin{tabular}{|c|c|c|c|c|c|c|c|c|}
\hline & \multicolumn{8}{|c|}{ Diet } \\
\hline & \multicolumn{2}{|c|}{$1(30,30)$} & \multicolumn{2}{|c|}{$2(30,30)$} & \multicolumn{2}{|c|}{$3(30,18)$} & \multicolumn{2}{|c|}{$4(30,29)$} \\
\hline & Mean & SE & Mean & SE & Mean & $\mathbf{S E}$ & Mean & $\mathrm{SE}$ \\
\hline \multicolumn{9}{|l|}{ Body-wt } \\
\hline at start of experiment (g) & $43 \cdot 9$ & $0 \cdot 4$ & $39 \cdot 6$ & $0 \cdot 4^{*}$ & $41 \cdot 8$ & $0 \cdot 5^{*}+$ & $37 \cdot 9$ & $0 \cdot 4^{*}+\ddagger$ \\
\hline at end of experiment (g) & $274 \cdot 3$ & $4 \cdot 4$ & $335 \cdot 5$ & $4 \cdot 6^{*}$ & $274 \cdot 9$ & $3.6 \dagger$ & $320 \cdot 6$ & $4 \cdot 1^{*+\ddagger}$ \\
\hline gain $(\mathrm{g})$ & $230 \cdot 1$ & $3 \cdot 3$ & 295.9 & $3 \cdot 3^{*}$ & $233 \cdot 1$ & $3 \cdot 2 \dagger$ & $282 \cdot 7$ & $3 \cdot 0^{*}+f$ \\
\hline Total feed consumption (g) & $640 \cdot 1$ & $5 \cdot 8$ & 783.8 & $5 \cdot 1$ & $647 \cdot 7$ & $3.7 \dagger$ & $764 \cdot 1$ & $6 \cdot 2^{*+t}$ \\
\hline Total energy consumption $\left(\mathrm{J} \times 10^{3}\right)$ & $11 \cdot 1$ & $0 \cdot 1$ & $13 \cdot 6$ & $0 \cdot 1^{*}$ & $11 \cdot 2$ & $0.6+$ & $17 \cdot 6$ & $0 \cdot 1 *+\hbar$ \\
\hline \multicolumn{9}{|l|}{ Feed efficiency } \\
\hline$\frac{\text { body-wt gain }(\mathrm{g})}{\text { food consumed }(\mathrm{g})}$ & $0 \cdot 36$ & 0.01 & 0.38 & $0 \cdot 01$ & $0 \cdot 36$ & 0.01 & $0 \cdot 36$ & $0 \cdot 01$ \\
\hline \multicolumn{9}{|l|}{ Energetic efficiency } \\
\hline body-wt gain (g) & $48 \cdot 4$ & $1 \cdot 2$ & $46 \cdot 0$ & $2 \cdot 5$ & $48 \cdot 1$ & $2 \cdot 1$ & $62 \cdot 2$ & $2 \cdot 9 * \dagger \ddagger$ \\
\hline
\end{tabular}

Significantly different from * diet $1(P<0.05), \dagger \operatorname{diet} 2(P<0.05)$, $\ddagger \operatorname{diet} 3(P<0.05)$. For details of diets, see Table 1.

Table 3. Effect of diet on the nature and amount $(\mathrm{mg} / \mathrm{kg}$ wet tissue) of rat gingival lipids (Mean values with their standard errors for two observations)

\begin{tabular}{|c|c|c|c|c|c|c|c|c|}
\hline & \multicolumn{8}{|c|}{ Diet } \\
\hline & \multicolumn{2}{|c|}{1} & \multicolumn{2}{|c|}{2} & \multicolumn{2}{|c|}{3} & \multicolumn{2}{|c|}{4} \\
\hline & Mean & SE & Mean & SE & Mean & $\mathrm{SE}$ & Mean & SE \\
\hline Total lipids & 328 & 8 & 250 & $12 \dagger$ & 298 & $6 \dagger$ & 365 & $5 \neq$. \\
\hline Total non-polar lipids & 254 & 4 & 172 & $3 \dagger$ & 229 & $5 t$ & 294 & $7 \ddagger$ \\
\hline Cholesterol esters & 24 & 2 & 9 & 1 & 26 & $4 f$ & 63 & $2+$ \\
\hline Triglycerides & 137 & 4 & 80 & $6 \dagger$ & 124 & $2+$ & 125 & $4+$ \\
\hline Free fatty acids & 12 & 1 & 15 & 1 & 10 & 2 & 29 & $2 \ddagger$ \\
\hline Free cholesterol & 58 & 2 & 61 & 4 & 48 & 4 & 62 & 2 \\
\hline Mono- and diglycerides & 23 & 1 & 7 & 1 & 21 & 1 & 15 & 2 \\
\hline Total polar lipids & 74 & 8 & 78 & 2 & 69 & 3 & 71 & 4 \\
\hline Total phospholipids* & 72 & $\cdot 4$ & 73 & 2 & 68 & 3 & 67 & 2 \\
\hline Phosphatidyl choline & 25 & 4 & 31 & 6 & 23 & 2 & 34 & 2 \\
\hline
\end{tabular}

* Phosphatidyl choline, phosphatidyl ethanolamine, sphingomyelin, phosphatidyl serine, phosphatidyl inositol and phosphatidic acid.

$\uparrow$ diet $1(P<0.05)$, diet $2(P<0.05)$.

For details of diets, see Table 1.

total non-polar and total polar lipids of gingival tissues are given in Tables 4 and 5 respectively. No significant difference was noted in the fatty acid composition of total non-polar and total polar lipids of gingival tissue of rats given the high-carbohydrate diet as compared with those given the high-protein diet, with the exception of 14:1 fatty acid for non-polar lipids. However, the high-fat diet caused accumulation of high levels of 
Table 4. Effect of diet on acyl group composition (weight \% of total fatty acids) of total non-polar lipids of rat gingiva

\begin{tabular}{|c|c|c|c|c|c|c|c|c|}
\hline \multirow[b]{3}{*}{ Fatty acid } & \multicolumn{8}{|c|}{ Diet } \\
\hline & \multicolumn{2}{|c|}{1} & \multicolumn{2}{|c|}{2} & \multicolumn{2}{|c|}{3} & \multicolumn{2}{|c|}{4} \\
\hline & Mean & $\mathbf{S E}$ & Mean & $\mathbf{S E}$ & Mean & $\mathrm{SE}$ & Mean & $\mathrm{SE}$ \\
\hline $14: 0$ & $2 \cdot 1$ & 0.1 & $2 \cdot 8$ & 0.2 & $2 \cdot 7$ & $0 \cdot 2$ & $1 \cdot 2$ & $0 \cdot 3$ \\
\hline $14: 1$ & 0.9 & $0 \cdot 1^{*}$ & $2 \cdot 1$ & 0.2 & $1 \cdot 0$ & $0 \cdot 1^{*}$ & 0.8 & $0 \cdot 1^{*}$ \\
\hline $15: 0$ & $2 \cdot 1$ & 0.2 & 1.9 & 0.1 & $1 \cdot 0$ & $0 \cdot 1^{*}$ & $1 \cdot 0$ & $0 \cdot 1^{*}$ \\
\hline $16: 0$ & $38 \cdot 3$ & $1 \cdot 4$ & $40 \cdot 2$ & 0.6 & $46 \cdot 6$ & $0.7^{*}$ & $32 \cdot 5$ & $1.6^{*}$ \\
\hline $16: 1$ & $8 \cdot 7$ & 0.6 & $8 \cdot 2$ & 0.3 & 6.7 & $0.6^{*}$ & $4 \cdot 8$ & 0.3 \\
\hline $18: 0$ & $9 \cdot 1$ & 0.3 & $12 \cdot 6$ & $1 \cdot 1$ & $14 \cdot 6$ & 0.8 & $14 \cdot 8$ & 0.9 \\
\hline $18: 1$ & $30 \cdot 0$ & 1.4 & $23 \cdot 6$ & 0.5 & $18 \cdot 2$ & $0 \cdot 6^{*}$ & $16 \cdot 2$ & $0 \cdot 3^{*}$ \\
\hline $18: 2$ & $4 \cdot 2$ & 0.5 & $3 \cdot 9$ & $0 \cdot 1$ & 3.6 & $0 \cdot 1$ & 14.9 & $0.6^{*}$ \\
\hline $18: 3$ & \multicolumn{2}{|c|}{ Trace } & 0.5 & 0.1 & \multicolumn{2}{|c|}{ Trace } & 1.9 & $0 \cdot 1^{*}$ \\
\hline $20: 0$ & $1 \cdot 3$ & 0.2 & 0.9 & $0 \cdot 1$ & 1.9 & $0 \cdot 2$ & $2 \cdot 1$ & $0 \cdot 1$ \\
\hline $20: 4$ & $2 \cdot 3$ & 0.1 & $2 \cdot 2$ & $0 \cdot 1$ & $2 \cdot 1$ & $0 \cdot 1$ & $3 \cdot 6$ & $0 \cdot 2$ \\
\hline $22: 0$ & $1 \cdot 0$ & $0 \cdot 1$ & $1 \cdot 1$ & 0.2 & 16 & 0.1 & 1.9 & $0 \cdot 1$ \\
\hline $22: 5$ & \multicolumn{2}{|c|}{ Trace } & \multicolumn{2}{|c|}{ Trace } & \multicolumn{2}{|c|}{ Trace } & $4 \cdot 3$ & 0.3 \\
\hline
\end{tabular}

* Statistically different from diet $2(P<0.05)$.

For details of diets, see Table 1.

Table 5. Effect of diet on acyl group composition (weight \% of total fatty acids) of total polar lipids of rat gingiva

(Mean values with their standard errors for two observations)

\begin{tabular}{|c|c|c|c|c|c|c|c|c|}
\hline \multirow[b]{3}{*}{ Fatty acid } & \multicolumn{8}{|c|}{ Diet } \\
\hline & \multicolumn{2}{|c|}{1} & \multicolumn{2}{|c|}{2} & \multicolumn{2}{|c|}{3} & \multicolumn{2}{|c|}{4} \\
\hline & Mean & $\mathbf{S E}$ & Mean & $\mathrm{SE}$ & Mean & $\mathrm{SE}$ & Mean & SE \\
\hline $14: 0$ & $3 \cdot 0$ & $0 \cdot 1$ & $3 \cdot 4$ & $0 \cdot 1$ & 1.9 & 0.2 & $3 \cdot 1$ & 0.2 \\
\hline $14: 1$ & $2 \cdot 9$ & 0.4 & 3.5 & 0.2 & 0.7 & $0 \cdot 1$ & 1.4 & $0 \cdot 1$ \\
\hline $15: 0$ & $1 \cdot 7$ & 0.3 & $2 \cdot 3$ & $0 \cdot 2$ & \multicolumn{2}{|c|}{ Trace } & $1 \cdot 3$ & $0 \cdot 1$ \\
\hline $16: 0$ & $37 \cdot 3$ & $1 \cdot 1$ & $40 \cdot 0$ & $1 \cdot 4$ & $52 \cdot 7$ & $0.6^{*}$ & $32 \cdot 6$ & $1 \cdot 1^{*}$ \\
\hline $16: 1$ & $5 \cdot 5$ & 0.5 & $4 \cdot 5$ & 0.2 & $6 \cdot 2$ & $0 \cdot 1$ & $4 \cdot 3$ & $0 \cdot 1$ \\
\hline 18:0 & $7 \cdot 8$ & 0.2 & $8 \cdot 1$ & 0.3 & $14 \cdot 8$ & $0.5^{*}$ & $11 \cdot 7$ & 0.6 \\
\hline $18: 1$ & $15 \cdot 5$ & $1 \cdot 1$ & $14 \cdot 7$ & $1 \cdot 1$ & $4 \cdot 6$ & $0.3^{*}$ & $11 \cdot 3$ & $0 \cdot 2$ \\
\hline $18: 2$ & $14 \cdot 8$ & $1 \cdot 2$ & $11 \cdot 7$ & 0.4 & $10 \cdot 1$ & 0.8 & $19 \cdot 7$ & $0 \cdot 4^{*}$ \\
\hline $18: 3$ & $3 \cdot 7$ & 0.4 & 1.9 & 0.1 & $2 \cdot 1$ & $0 \cdot 1$ & $2 \cdot 3$ & $0 \cdot 1$ \\
\hline $20: 0$ & $1 \cdot 2$ & $0 \cdot 1$ & 0.5 & 0.1 & 1.5 & $0 \cdot 1$ & $1 \cdot 1$ & $0 \cdot 1$ \\
\hline $20: 4$ & 3.9 & 0.1 & $5 \cdot 8$ & 0.2 & $3 \cdot 5$ & $0 \cdot 2$ & $5 \cdot 2$ & $0 \cdot 1$ \\
\hline $22: 0$ & 1.5 & 0.2 & \multicolumn{2}{|c|}{ Trace } & 1.9 & $0 \cdot 1$ & 0.6 & $0 \cdot 1$ \\
\hline $22: 5$ & $1 \cdot 2$ & $0 \cdot 1$ & 3.6 & $0 \cdot 1$ & \multicolumn{2}{|c|}{ Trace } & $5 \cdot 4$ & $0 \cdot 2^{*}$ \\
\hline
\end{tabular}

* Statistically different from that of diet $2(P<0.05)$.

For details of diets, see Table 1.

polyunsaturated fatty acids such as linoleic and docosapentaenoic acid, whereas the extremely high-protein diet caused significant increases in the levels of saturated fatty acids.

DISCUSSION

It is difficult to determine why diet 2 yielded values that were markedly different from the other three, because its protein content was intermediate to that of diets 1 and 3, and similar 
to that of diet 4 . Diet 1 is reasonably adequate in protein, but the high-protein content of diet 2 might be expected to stimulate growth. Diet 3 has such an unnaturally high protein content that it might be expected to cause problems for the animals - for whatever reason, the mortality rate was extraordinarily high. An explanation, however, cannot simply be in terms of protein content alone, but must involve some other complicated interaction between protein, carbohydrate and fat contents and energy density.

The most surprising feature is the inefficient use for weight gain of the energy in diet 4. A diet providing more that $50 \%$ its energy in the form of fat is likely to be harmful to rats, and it is doubtful whether useful nutritional conclusions can be drawn from results with such a diet.

It must be noted here that diet also is known to influence oral flora and no correlation has been established in this study between lipid composition changes and pathology of gingival tissue. Furthermore, we do not know at this time to what extent the results for gingiva may be explained by surface adherence to gingival muscosa or even some permeation among the keratinized cells. If any appreciable amount of fat accumulates on the surface of gingiva, the potential is there for bacterial interactions that could change the composition of the lipids differently in the presence of a high-carbohydrate low-fat diet $v$. a low-carbohydrate high-fat diet. It seems that the present results relating to the effect of diets on the quality and quantities of lipids and fatty acids in gingival tissue must be supplemented with further information, including surface adherence of lipids, before firm conclusions may be drawn. Nevertheless, the present study reveals that the dietary feeding of the high-cottonseed-oil diets causes a two- to four-fold increase in the proportion of linoleic acid in total fatty acids of both the polar and non-polar lipids of gingival tissue. Thus the lipids in gingival tissue are responsive to diet and are in dynamic equilibrium with some of the dietary components.

This investigation was supported by USPHS Grant DE-03191 and RR-08037-10 from the National Institutes of Health, Bethesda, Maryland.

\section{REFERENCES}

Abdel-Hay, A. A., Kramer, M., Szotyori, K. \& Tarjan, R. (1968). Nahrung 12, 213.

Bartlett, G. R. (1958). J. biol. Chem. 234, 466.

Courchaine, A. J., Miller, W. H. \& Stein, D. B. Jr. (1959). Clin. Chem. 5, 609.

Das, S. K., Adhikary, P. K. \& Bhattacharyya, D. K. (1976a). J. Dent. Res. 55, 182.

Das, S. K., Adhikary, P. K. \& Bhattacharyya, D. K. (1976b). J. Dent. Res. 55, 185.

Das, S. K., Adhikary, P. K. \& Bhattacharyya, D. K. (1976c). J. Dent. Res. 55, 602.

Das, S. K., Scott, M. T. \& Adhikary, P. K. (1975). Lipids 10, 584.

Mangold, H. K. \& Malins, D. C. (1960). J. Am. Oil Chem. Soc. 37, 383.

Metcalf, L. D. \& Schmitz, A. A. (1961). Analyt. Chem. 33, 363.

Novak, M. (1965). J. Lipid Res. 6, 431.

Parker, F. \& Peterson, N. R. (1965). J. Lipid Res. 6, 455.

Prout, R. E. S. \& Tring, F. C. (1971 a). J. Periodont. Res. 6, 182.

Prout, R. E. S. \& Tring, F. C. $(1971 b)$. J. Dent. Res. 52, 462.

Rabinowitz, J. L., Bailey, T. A. \& Marsh, J. B. (1971). Arch. Oral Biol. 16, 1195.

Stahl, S. S. (1963). J. Dent. Res. 42, 1511.

Steel, R. G. D. \& Torrey, J. H. (1960). Principles and Procedures in Statistics. New York: McGraw-Hill Book Co.

US Pharmacopoea (1945). US Pharmacopoea, vol. XIII, no. 2, Salt Mix, p. 721.

Van Handel, E. \& Zilversmit, D. B. (1957). J. Lab. clin. Med. 50, 152.

Wysocki, E. \& Ziombski, H. (1963). Roczniki Pzh. 14, 299. 